\title{
QUANTITATIVE AUTORADIOGRAPHY OF L-['3]GLUTAMATE BINDING TO RAT BRAIN
}

\author{
JOHN T. GREENAMYRE, ANNE B. YOUNG* and JOHN B. PENNEY
}

University of Michigan, Neuroscience Lab. Building, I103 East Huron, Ann Arbor, MI 48109 (U.S.A.)

(Received February 22nd, 1983; Accepted March 7th, 1983)

Key words: glutamate - receptors - autoradiography - hippocampus - striatum - cortex - cerebellum

\begin{abstract}
A technique has been developed to investigate sodium-independent $\mathbf{L}-\left.\right|^{3} \mathrm{H}$ /glutamate binding in rat brain sections using quantitative autoradiography and tritium-sensitive film. Binding is rapid (reaching equilibrium in $5 \mathrm{~min}$ ) and reversible (having $\mathrm{t}_{1 / 2}$ of dissociation of $0.38 \mathrm{~min}$ ). Glutamate apparently bound to a single population of sites with a $K_{d}$ of about $1.0 \mu \mathrm{M}$. The pharmacology of this binding site is similar to that observed in homogenate studies. There is marked regional variation in the amount of glutamate bound. Of the areas analyzed in detail, the density of sites is greatest in stratum moleculare of hippocampus, followed by striatum and cortex.
\end{abstract}

Abundiant electrophysiological and biochemical evidence supports the role of glutamate as a putative excitatory neurotransmitter in the mammalian central nervous system (CNS). The examination of biochemical markers for the neurotransmitter pool of glutamate, such as high-affinity uptake and $\mathrm{Ca}^{2+}$-dependent release, in conjunction with lesion studies, has led investigators to propose numerous glutamatergic pathways including: corticostriate [5, 12]; corticothalamic and corticospinal [23]; perforant path [21]; hippocampal commissural [13]; and cerebellar granule cell [22] pathways. Recently, high affinity binding of $\left.L-l^{3} \mathrm{H}\right]$ glutamate to membrane fractions of CNS has been demonstrated by several laboratories [1, 3, $6,20] . \mathrm{L}-\left[^{3} \mathrm{H}\right]$ Glutamate binding is saturable and reversible, is highest in fractions enriched in synaptic junctions [4], is inhibited by various glutamate analogues and antagonists of glutamate-induced depolarization, and appears to be related to synaptic glutamate receptors. Attempts to define the anatomical localization of glutamate binding sites have until recently been limited by available dissection methods [7] and have yielded contradictory results $[1,3,9]$. With the development of quantitative receptor autoradiography, using either the emulsion technique or tritium-sensitive film, the precise regional distribution of various receptor types has been described $[10,14,15,17,24]$. It has been technically difficult to apply

- Author for correspondence.

0304-3940/83/0000-0000/\$03.00 (c) 1983 Elsevier Scientific Publishers Ireland Ltd. 
autoradiographic techniques to glutamate binding because glutamate binding sites typically have dissociation constants in the high nanomolar to low micromolar range and an extremely rapid dissociation rate. Recently, however, a brief, preliminary report indicated that autoradiography of glutamate binding sites may be feasible [8]. We report here the use of quantitative autoradiography to study kinetic, saturation and competition data of $\left[{ }^{3} \mathrm{H}\right]$ glutamate binding in highly localized regions of rat broin.

Sprague-Dawley male rats (150-175 g) were decapitated, the brains quickiy removed, blocked, placed in ice-cold buffered $0.32 \mathrm{M}$ sucrose (pH 7.4) and allowed to cool to about $4^{\circ} \mathrm{C}$. The tissue was then mounted on a microtome chuck with Lipshaw embedding matrix and frozen under powdered dry ice. Twenty $\mu \mathrm{m}$ coronal brain sections were cut on a Lipshaw cryostat and thaw-mounted onto subbed slides. Sections were washed for $30 \mathrm{~min}$ in ice-cold $50 \mathrm{mM}$ Tris- $\mathrm{HCl}(\mathrm{pH} 7.4)$. containing $2.5 \mathrm{mM} \mathrm{CaCl}$, in order to remove endogenous glutamate and then were blown dry with a stream of cool air. The tissue was routinely incubated for $\mathbf{3 0}$ min
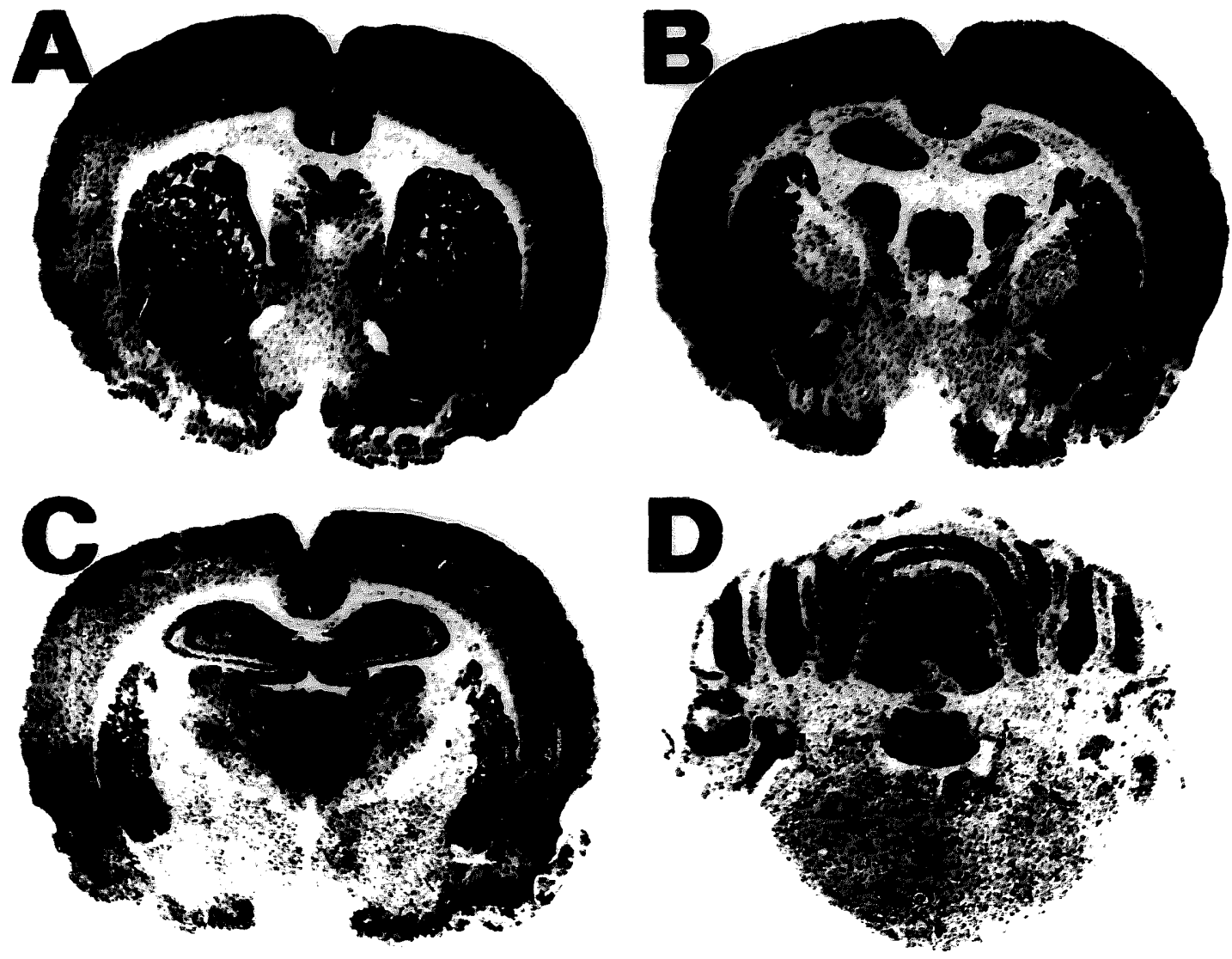

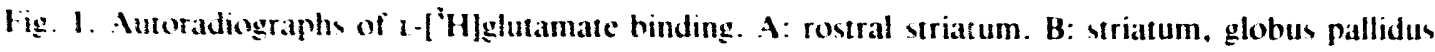
and rovtral hippocampus. ( : hippocampus, thalamus and hypothalanus. D: cerebellum and medulla. 1 - fHjchutamatc concentration was $97 \mathrm{n} .11$. 
at $37^{\circ} \mathrm{C}$ with various concentrations $(50-1000 \mathrm{nM})$ of $\left[{ }^{3} \mathrm{H}\right]$ glutamate $(43 \mathrm{Ci} / \mathrm{mmol}$, Amersham) in $50 \mathrm{mM}$ Tris- $\mathrm{HCl}$ containing $2.5 \mathrm{mM} \mathrm{CaCl}$. Sections were incubated for 0-30 min for kinetic studies. In competition studies unlabeled drugs were included in the assay mixture. Non-specific binding was determined in the presence of 1 mM unlabeled glutamate. Non-specific binding represented $25-35 \%$ of total binding at $\left[{ }^{3} \mathrm{H}\right]$ glutamate concentrations of 50-1000 $\mathrm{nM}$. However, at higher ligand concentrations non-specific binding represented a higher proportion of total binding. After the incubation, sections were rinsed 3 times with cold buffer, followed by a rinse with cold $5 \%$ glutaraldehyde in acetone in order to dry the slides rapidly and minimize uneven dissociation during drying. The total rinse time was approximately $10 \mathrm{sec}$. For dissociation studies the sections received 3 standard buffer rinses, followed by immersion in a large volume ('infinite dilution') of cold buffer for various times (15 sec to $10 \mathrm{~min}$ ), and finally the glutaraldehyde/acetone rinse. Slides were blown dry with warm air, placed in X-ray cassettes with appropriate standards (16) and apposed to Ultrofilm ${ }^{3} \mathrm{H}$ (L.KB).

After a 14-21-day exposure at $4^{\circ} \mathrm{C}$, the film was developed in D-19 for $4 \mathrm{~min}$ at $20^{\circ} \mathrm{C}$, fixed and dried. The film was placed in a photographic enlarger and the optical densities of areas of film determined with a computer-assisted microdensitometer, located at the center of the enlarger's image plane. Sixteen readings from each region were averaged and the radioactivity was determined by a computergenerated polynomial regression analysis, which compared film densities produced by the sections with those produced by the standards, as previously described [16].

The binding of L-I'H/glutamate to tissue sections showed marked regional heterogeneity (Fig. 1). Cortex, striatum, hippocampus and the molecular layer of the cerebellum all are thought to receive extensive glutamatergic input, and by this technique show the highest densities of binding sites. It is of interest that in hippocampus and cerebellum the density of sites is heaviest in stratum moleculare and the molecular layer, respectively, areas sparse in neuronal cell bodies where dendritic arborization and putative glutamatergic synaptic activity are extensive [18]. This is consistent with findings from hippocampus [2] and cerebellum [19] that the ontogeny of glutamate binding sites closely parallels the development of the hippocampal molecular layers and the parallel fiber system, respectively, and further suggests that these sites are related to postsynaptic glutamate receptors.

Scatchard analysis of glutamate binding reveals an apparent single homogeneous population of binding sites with a $K_{d}$ of about $1 \mu \mathrm{M}$ (Fig. 2A). Data analyzed from 3 regions of forebrain indicate that the density of binding sites is greatest in the stratum moleculare of the hippocampus, $\left(K_{d}=960 \pm 35 \mathrm{nM}, \mathrm{B}_{\max }=1.99 \pm 0.08\right.$ $\mathrm{pmol} / \mathrm{mg}$ tissue) followed by striatum $\left(K_{d}=891 \pm 96 \mathrm{nM}, B_{\max } 1.17 \pm 0.09\right.$ $\mathrm{pmo} ! / \mathrm{mg}$ tissue $)$ and cortex, layers 5 and $6\left(K_{d}=957 \pm 46 \mathrm{nM}, \mathrm{B}_{\max }=1.08+\right.$ $0.18 \mathrm{pmol} / \mathrm{mg}$ tissue). Hill coefficients of 1.0 were calculated from these saturation data, suggesting an apparent single class of binding sites. However, it should be noted that the saturation curves have not as yet been carried to very high ligand con- 

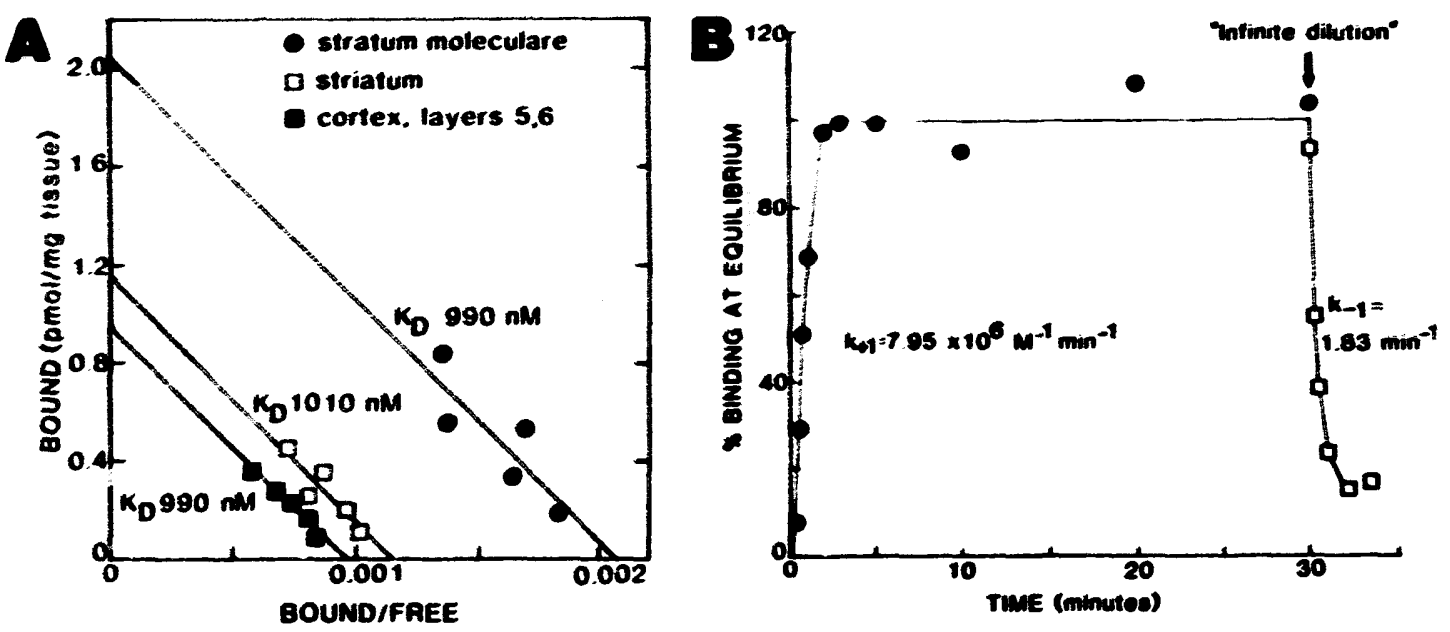

Fig. 2.A: representative Scatchard plots of $\mathrm{L}-\left[^{3} \mathrm{H}\right]$ glutamate binding in stratum moleculare of hippocampus $\left(B_{\text {mat }}=2.05 \mathrm{pmol} / \mathrm{mg}\right.$ tissue, $\left.r=0.86\right)$; 5 iriatum $\left(B_{\text {max }}=1.16 \mathrm{pmol} / \mathrm{mg}\right.$ tissue, $\left.r=0.89\right)$; and corIex. layers 5 and $6\left(B_{\text {mas }}=0.95 \mathrm{pmol} / \mathrm{mg}\right.$ tissue, $\left.r=0.98\right)$. Ligand concentrations between 100 and 600 nM were used in this experiment. Autoradiography was performed as described in text. Each point represents specific binding (the average of 16 readings in an arca of interest minus readings from adjacent sections incubated in presence of $1 \mathrm{mMI}$ gitumate). The experiment has been replicated 3 times. B: association and dissociation of $1 .-\left[{ }^{3} \mathrm{H}\right] \mathrm{glutamate}$ binding. Data were taken from striatum. The concentration of $\left.\left.\right|^{3} \mathrm{H}\right] \mathrm{glutamate}$ was $97 \mathrm{nM}$. Points represent specific binding. Tissue was incubated for $0-30 \mathrm{~min}$ for association studies (closed circles) and additional sections were rinsed as described in text for dissociation studies (open squares).

centrations for technical reasons and thus it is possible that additional lower affinity sites exist [1I]. This possibility is currently under investigation.

The binding of I'H $^{3} \mathrm{Hglutamate}$ to sections was rapid and reached equilibrium within $5 \mathrm{~min}$ (Figure 2B). Binding was stable for at least $30 \mathrm{~min}$. The association rate constant $\left(k_{1}\right)$ was determined to be $8.47 \pm 0.72 \times 10^{6} \mathrm{M}^{-1} \min { }^{-1}$. After 30

\section{TABLE I}

INHIBITION OF SPECIFIC BINDING OF L-['H]GLUTAMATE BY VARIOUS GLUTAMATE ANAIOGUES.

Analogues were lested al $100 \mu \mathrm{M}, 1 \mathrm{mM}$ and $5 \mathrm{mM}$. The concentration of $\mathrm{L}-$ [ $\left.^{3} \mathrm{H}\right] \mathrm{glutamate}$ was $47 \mathrm{nM}$. Values represent averages of 2 or 3 experiments. Data were taken from striatum.

\begin{tabular}{|c|c|c|c|}
\hline \multirow[t]{2}{*}{ Drug } & \multicolumn{3}{|c|}{ \%o Displacement } \\
\hline & $5 \mathrm{mM}$ & $\mathbf{m} \mathbf{m M}$ & $100 \mu \mathrm{M}$ \\
\hline Quisqualic acid & 79 & 81 & 49 \\
\hline Ibolenic acid & $74^{3}$ & 73 & 32 \\
\hline L-Aspartic acid & 64 & 44 & 23 \\
\hline D.I-Homocystcic acid & 71 & 46 & 18 \\
\hline D,L-o-Aminoadipic acid & 55 & 37 & 4 \\
\hline D,1-2-Amino-4-phosphonobutyric acid & 39 & 17 & 0 \\
\hline Kainic acid & 26 & 21 & 9 \\
\hline N-Methyl-D,L-aspartic acid & 12 & 8 & 11 \\
\hline
\end{tabular}

$2.5 \mathrm{m.M}$ 
min of incubation, when sections at equilibrium were placed in $300 \mathrm{ml}$ of cold buffer ('infinite dilution'), the bound glutamate quickly dissociated from the binding site with a half time of $0.38 \mathrm{~min}$. This half time corresponds to a dissociation rate cons$\operatorname{tant}\left(k_{-1}\right)$ of $1.83 \pm 0.01 \mathrm{~min}^{-1}$. The ratio, $k_{-1} / k_{1}$, is an estimate of the equilibrium dissociation constant of binding and gives a $K_{d}$ of $216 \mathrm{nM}$. This $K_{d}$ value is roughly within the range of that found from equilibrium saturation studies, the difference probably reflecting the difficulties inherent in measuring such rapid rates of association and dissociation.

In displacement studies unlabelled glutamate was the most potent inhibitor of $\left[{ }^{3} \mathrm{H}\right]$ glutamate binding. Other compounds were tested at concentrations of $100 \mu \mathrm{M}$, $1 \mathrm{mM}$ and $5 \mathrm{mM}$ for their ability to inhibit binding in striatum (Table I). The cyclic glutanate analogues, quisqualate and ibotenate, were the next most potent diplacers, followed by D,L-homocysteic acid and L-aspartate. The putative antagonists, D,L- $\alpha$-aminoadipic acid and D,L-2-amino-4-phosphonobutyric acid, were of intermediate potency. Kainic acid and $\boldsymbol{N}$-methyl-D,L-aspartate were almost inactive. This rank order of potencies of the displacers is virtually identical to that of Foster and Roberts [6] using a cerebellar membrane preparation. It must be kept in mind, however, that glutamate binding sites in different areas of brain could exhibit distinct pharmacological specificities.

This report indicates that detailed kinetic, saturation and competition data on L$\left.{ }^{3} \mathrm{H}\right]$ glutamate binding can be obtained autoradiographically from highly circumscribed regions of brain. The data presented are consistent with reports from other laboratories using homogenate techniques and suggest that the glutamate binding site is related to postsynaptic glutamate receptors. Further support for this hypothesis is the fact that regions of brain suspected to receive extensive glutamatergic input show the greatest density of binding sites. In particular, autoradiography provides direct evidence that relatively acellular regions that are rich in dendritic processes and putative glutamatergic synapses show a high density of binding sites.

This work was supported by NSF Grant BNS-8118765 and United Cerebral Palsy Foundation Grant R-305-82 and a NIMH Individual Predoctoral National Research Service Award to J.T.G. (1 F31 MH08922-01).

I Baudry, M. and Lynch, G., Characterization of two $\left[{ }^{3} H\right]$ glutamate binding sites in rat hippocampal membranes, J. Neurochem., 36 (1981) 811-820.

2 Baudry, M. and Lynch, G., Hippocampal glutamate receptors, Molec. cell. Biochem., 38 (1981) 5-18.

3 Biziere, K., Thompson, H., and Coyle, J.T., Characterization of specitic, high-affinity binding sites for $1-\left[{ }^{3} \mathrm{H}\right]$ glutamic acid in rat brain membranes, Brain Res., 183 (198:) 421-433.

4 Cotman, C.W., Foster, A. and Lanthorn, T., An overview of glutamate as a neurotransmitter. In G. Di Chiara and G.L. Gessa (Eds.), Glutamate as a Neurotransmitter, Advances in Biochemical Psychopharmacology, Vol. 27, Raven Press, New York, 1981, pp. 1-27. 
5 Divac, 1., Fonnum, F. and Storm-Mathisen, J., High affinity uptake of glutamate in terminals of corticostriatal axons, Nature (Lond.), 266 (1977) 377-378.

6 Foster, A.C. and Roberts, P.J., High affinity L-[ $\left.{ }^{3} \mathrm{H}\right]$ glutamate binding to postsynaptic receptor sites on rat cerebellar membranes, J. Neurochem., 34 (1978) 1467-1477.

7 Glowinski, J. and Iverson. L.L., Regional studies of catecholamines in the rat brain, J. Neurochem., 13 (1966) 655-669.

8 Halpain. S., Parsons, B. and Rainbow. T.C.. Tritium-film autoradiography of sodium-independent glutamate binding sites in rat brain, Europ. J. Pharmacol., 86 (1983) 313-314.

9 Head, R.A., Tunnicliff, G. and Matheson, G.K.. Glutamate receptor binding to cat central nervous system membranes. Canad. J. Biochem. 58 (1980) 534-538.

10 Herkenham. M. and Pert. C.B.. In vitro autoradiography of opiate receptors in rat brain suggest loci of 'opiatergic' pathways, Proc, nat. Acad. Sci. U.S.A., 77 (1981) 5532-5536.

11 Klotz. I.M. Numbers of receptor sites from Scatchard graphs: facts and fanty :es. Science, 217 (1982) $1247-1249$.

12 McGeer, P.I... McGeer. E.G.. Scherer, U. and Singh. K.. A glutamatergic corticostriate path? Brain Res.. 128 (1977) 369- 373.

13 Nadler, J.V., White. W.F., Vaca, K.W., Perry, B.W. and Cotman, C.W., Biochemical correlates of transmission mediated by glutamate and aspartate, J. Neurochem., 31 (1978) 147-155.

14 Palacios, J.M., Niehoff. D.L. and Kuhar, M.J.. Receptor autoradiography with tritium sensitive film: potential for computerized densitometry. Neurosci. Lett., 25 (1981) 101-105.

15 Penney, J.B.. Frey. K.A. and Young. A.B., Quantitative autoradiography of neurotransmitter receptors, Europ. J. Pharmacol., 72 (1981) $421-422$.

16 Penney, J.B., Pan. H.S., Young. A.B., Frey. K.A. and Dauth. G.W., Quantitative auturadiography of ('H)muscimol binding in rat brain. Science. 214 (1981) 1036-1038.

17 Rainbow. T.C., Bleisch, W.V., Biegon, A, and McEwen, B.S., Quantitative densitumetry of neurotransmitter receptors, J. Neurosci. Meth., 5 (1981) 127-138.

I8 Shepherd, (i.M., The Synaptic (Organization of the Brain, Oxford University Press, New York, 1979. $\$ 36 \mathrm{pm}$.

19 Slevin, J.T, and ('oyle. J, T. (Ontogeny of receptor binding sites for ('H/glutamic acid and ['H]katnic acid in the rat cercbellum, J. Neurochem., 37 (1981) 531-533.

20) Werling, I. I. and Nadler. J.V.. ( 'omplex binding of 1-I'H/glutamate to hippocampal synaptic membranes in the absence of sodium, J. Neurochem., 38 (1982) 1050-1062.

21 White, W.F., Nadler. J.V., Hamberger. A.. Cotman, C.W. and Cummins, J.T., Glutamate as transmitter of hippocampal perforant path, Nature (Lond.), 270 (1977) 356-357.

22 Young. A.B., Oster-Granite, M.L.. Herndon, R.M. and Snyder, S.H., Glutamic acid: selective depletion by viral induced granule cell loss in hamster cercbellum, Brain Res., 72 (1974) 1-13.

23 Young, A.B., Bromberg. M. and Penney. J.B., Decreased glutamate uptake in subcortical areas deafferented by sensorimotor cortical ablation in the cat, J. Neurosci., 1 (1981) 241-249.

24 Young, W.S., III and Kuhar, M.J.. A new method for receptor autoradiography: ['H Jopioid receptor labelling in mounted tissue sections. Brain Res., 179 (1979) 255-270. 